\title{
Water quality assessment of Aguamilpa Reservoir, Nayarit, Mexico
}

\author{
J. G. Rangel-Peraza ${ }^{1}$, J. De Anda ${ }^{1}$, F. A. González-Farias ${ }^{2}$ \\ \& D. E. Erickson ${ }^{1}$ \\ ${ }^{1}$ Unidad de Tecnología Ambiental, Centro de Investigación y Asistencia \\ en Tecnología y Diseño del Estado de Jalisco A. C., México \\ ${ }^{2}$ Instituto de Ciencias del Mar y Limnología, Universidad Nacional \\ Autónoma de México, México
}

\begin{abstract}
An analysis of water quality data is presented for the Aguamilpa reservoir located in a tropical region of the state of Nayarit, Mexico. The analysis includes physicochemical and biological data including total chlorophyll and blue-green algae concentrations obtained at different depths during the period of June 2008 to April 2009. The observed measurements show that the reservoir is stratified during all the study period and has a relatively high primary productivity. The relatively high blue-green algae concentration on the surface waters indicates that eutrophication process occurs in this young reservoir which began operations in 1994. This eutrophication process may be explained by the nutrients enrichment in the system, relatively warm temperatures intrinsic to the tropical region where the reservoir is located, low turbulence in lower layers and stable circulation patterns due to the narrow morphology of the steep canyon walls where the reservoir is located.
\end{abstract}

Keywords: Aguamilpa reservoir, water quality, blue-green algae, meromictic circulation.

\section{Introduction}

Reservoir construction continues at a rapid pace, in particular in the developing world, where demand of water and electricity is strongest as a consequence of population growth [1]. The interventions in the natural hydrologic cycle by damming of the rivers are usually undertaken with a beneficial socio-economic 
objective in mind. The experience has evidenced, however, that the long term results of the environmental degradation frequently exceed those benefits. The contamination and degradation of water quality interferes with the water uses at any scale (local, regional or international) [2]. In fact, it has been demonstrated that the restoration of the aquatic ecosystem and water quality of large reservoirs can be considered irreversible [3].

The present-day knowledge on water quality of freshwaters at tropical regions is based on the studies that have been developed in last decades especially in low latitudes of the tropic $[4,5]$; however, these studies are restricted since they focus on tropical water bodies located at high altitudes which are shallower that those located at low altitude zones $[6,7]$.

In Mexico, reservoirs have been built primarily to store large volumes of water used for power generation. Therefore, little is known about the water quality conditions of lakes and reservoirs despite the fact that they represent almost $70 \%$ of the storage capability of surface waters [8]. In particular, studies related to water quantity and quality for the Aguamilpa reservoir are recent [9$13]$.

Basic features of the physical, chemical and biological limnology of Aguamilpa reservoir, a large impoundment on the Santiago and Huaynamota rivers, were studied during the period of June 2008 to April 2009. The main objective of this paper is to provide baseline knowledge of the general water quality features of Aguamilpa reservoir.

\section{Materials and methods}

\subsection{Study area}

Since the mid nineteenth century, four large hydroelectric power plants have been constructed in the basin of the Santiago River, one of the most important and largest rivers in Mexico, in which the Aguamilpa reservoir is included. The poor water quality of Santiago River it has been recognized due to non-point wastewaters discharges from Guadalajara city metropolitan area, the excessive use of fertilizers, and land use changes [14].

The Aguamilpa reservoir is located between $21^{\circ} 23^{\prime}$ and $21^{\circ} 56^{\prime} \mathrm{N}$, and $104^{\circ}$ $25^{\prime}$ and $104^{\circ} 49^{\prime} \mathrm{W}$ (fig. 1), $305 \mathrm{~km}$ downstream from Guadalajara city metropolitan area, the second largest city in Mexico. The reservoir is part of the Santiago-Aguamilpa and Huaynamota hydrologic systems and it occupies approximately $60 \mathrm{~km}$ along the Santiago River and $25 \mathrm{~km}$ along the Huaynamota River. Aguamilpa reservoir was built between 1989 and 1994, primarily to meet growing demands for hydropower generation and flood control; irrigation and fishery usage being secondary. Relevant morphometric and hydrological characteristics of the reservoir are summarised in table 1 .

The regional hydrological and climate features where the reservoir is located are characterized by the existence of three seasons: a rainy season that lasts from July to October, a cold dry season from November to February and a warm dry season from March to June [13, 15]. 
Table 1: $\quad$ Morphometric and hydrological features of Aguamilpa reservoir $[16,50]$.

\begin{tabular}{|l|l|}
\hline \multicolumn{2}{|c|}{ Catchment attributes } \\
\hline Catchment area $\left(\mathrm{km}^{2}\right)$ & 7,991 \\
\hline Mean annual runoff $\left(\mathrm{Mm}^{3}\right)$ & 595 \\
\hline \multicolumn{2}{|c|}{ Reservoir attributes } \\
\hline Total storage volume $\left(\mathrm{Mm}^{3}\right)$ & 5,540 \\
\hline Surface area $\left(\mathrm{km}^{2}\right)$ & 109 \\
\hline Maximum depth $(\mathrm{m})$ & 187 \\
\hline Mean depth $(\mathrm{m})$ & 50 \\
\hline
\end{tabular}

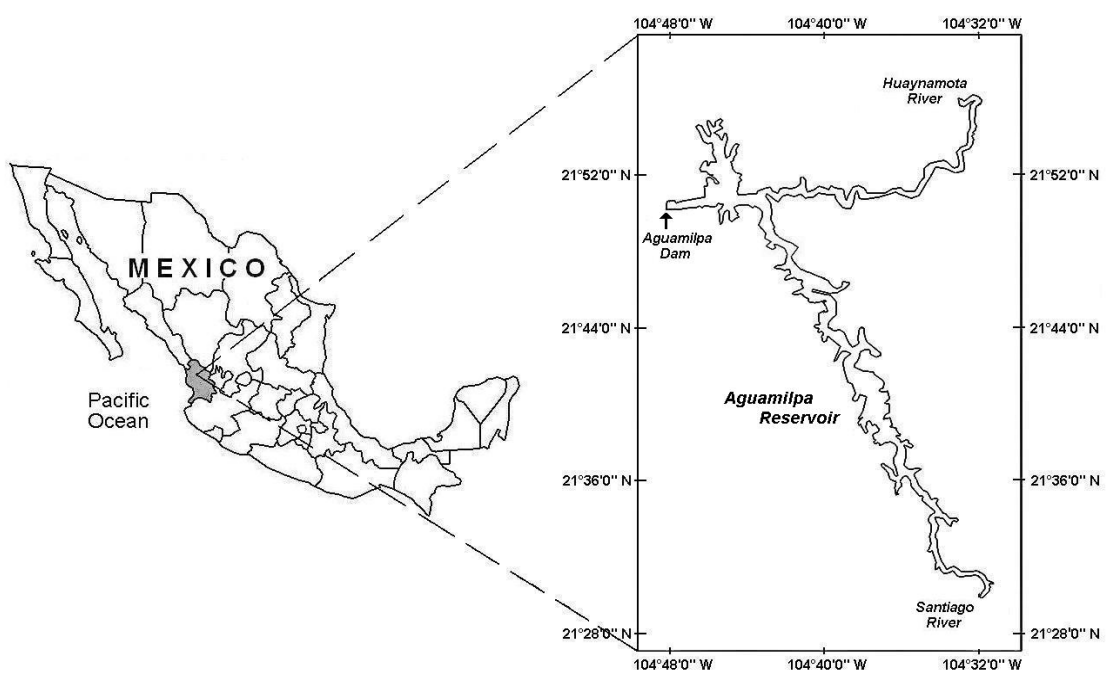

Figure 1: Geographic location of Aguamilpa reservoir.

The bottom of Aguamilpa concrete faced rock-fill dam is located at 48 m.a.s.1. with the crest elevation at 235 m.a.s.1., and a length of $660 \mathrm{~m}$. [16, 17]. The reservoir has a maximum storage water level of 220 m.a.s.l. and the water used for power generation is taken at 170 m.a.s.l.

\subsection{Sampling}

Aguamilpa reservoir was sampled every two months between June 2008 and April 2009. Sampling was always undertaken between 12:00 and 14:00 hours at one station located at $21^{\circ} 50^{\prime} 23^{\prime \prime} \mathrm{N}$ and $104^{\circ} 47^{\prime} 58^{\prime \prime} \mathrm{W}$, next to the dam wall, which is the deepest part of the reservoir. Vertical profiles of temperature, 
dissolved oxygen, $\mathrm{pH}$, oxidation-reduction potential (Eh), conductivity, total chlorophyll and blue-green algae were measured twice using a water quality probe (YSI Model 6600D). For dissolved oxygen and $\mathrm{pH}$ the probe was always calibrated in situ before sampling. Regular control measurements of dissolved oxygen concentration were made by Winkler's method [18].

The YSI chlorophyll system consists of a probe with a similar principle of operation to the sonde-type fluorometers which induce chlorophyll to fluoresce by shining a beam of light of the proper wavelength $(470 \mathrm{~nm})$ into the sample, and then measuring the higher wavelength light (between 650 and $700 \mathrm{~nm}$ ) which is emitted as a result of the fluorescence process. The ability of phycocyanin only to fluoresce between the 600 and $700 \mathrm{~nm}$ region of the spectrum while present in whole blue-green algae cells is the basis for blue-green algae determinations in this study [19].

A real time weather station, located at $21^{\circ} 50^{\prime} 32^{\prime \prime} \mathrm{N}$ and $104^{\circ} 46^{\prime} 29^{\prime \prime} \mathrm{W}$, operated by Federal Commission of Electricity (CFE) was used to monitor the daily precipitation, air temperature and water level of the reservoir [20].

\section{Results}

The hydrological and climatic characteristics of the study area are described in fig. 2. The rainy season goes from July to October, reaching a maximum monthly average of $531.4 \mathrm{~mm}$ in July 2008. Air temperature of Aguamilpa reservoir showed a monthly variation interval from $23.1^{\circ} \mathrm{C} \pm 0.1$ in December 2008 to $28.6^{\circ} \mathrm{C} \pm 0.5$ in May 2008 with a mean annual temperature of $26.1 \pm$ $0.1^{\circ} \mathrm{C}$. The highest volume stored in Aguamilpa reservoir $(5,786.19 \pm 36.26$ $\left.\mathrm{Mm}^{3}\right)$ was recorded in September 2008, whereas the lowest volume $(3,197.38 \pm$ $2.97 \mathrm{Mm}^{3}$ ) was recorded at the beginning of July 2008 .

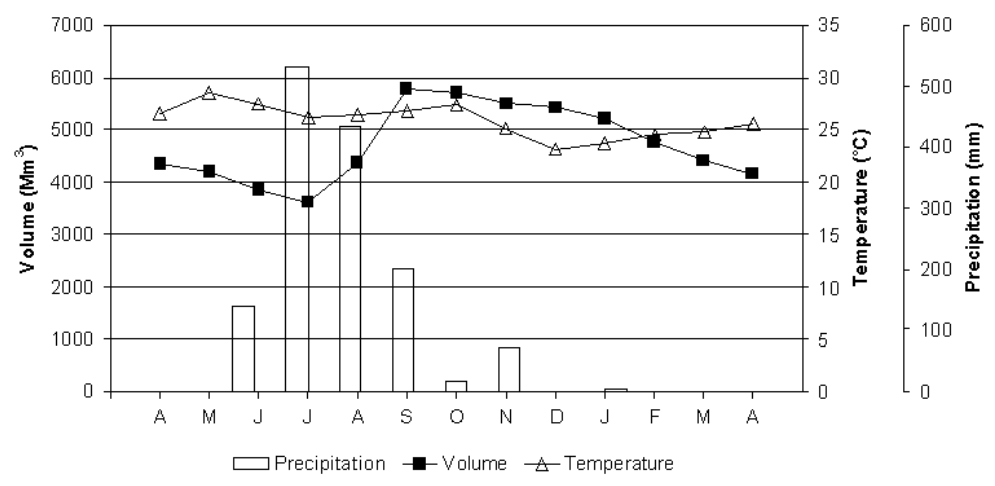

Figure 2: Monthly average of precipitation, air temperature and volume stored in Aguamilpa reservoir from April 2008 to April 2009.

The thermal profiles of Aguamilpa reservoir during the study period are shown in fig. 3. The reservoir showed a thermal stratification from June to October 2008. The surface water temperature, depending on the season, varied 
from $29.5^{\circ} \mathrm{C}$ in August to $23.9^{\circ} \mathrm{C}$ in February 2009. During the cold dry season, temperature was practically homogenous in the water column due to the decrease of surface temperature. Thermal conditions in deeper waters of Aguamilpa reservoir changed slightly within the study period, from $23.2^{\circ} \mathrm{C}$ to $23.5^{\circ} \mathrm{C}$.

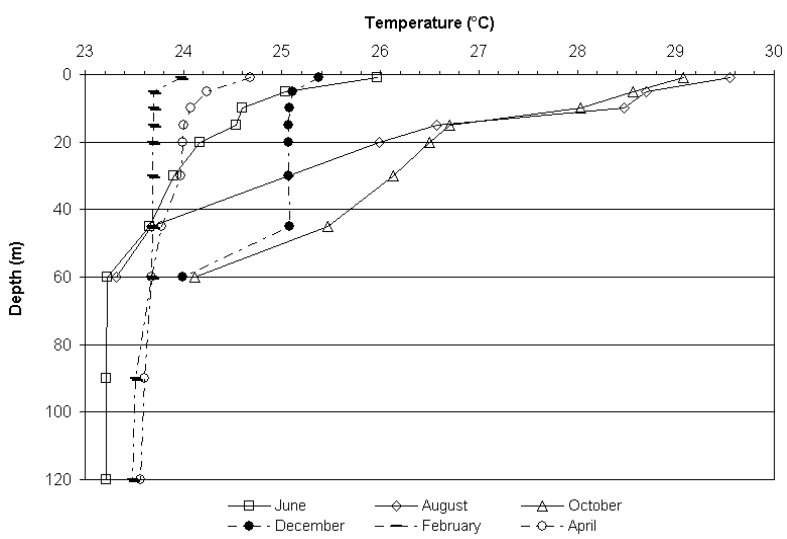

Figure 3: $\quad$ Thermal profiles of Aguamilpa reservoir from June 2008 to April 2009.

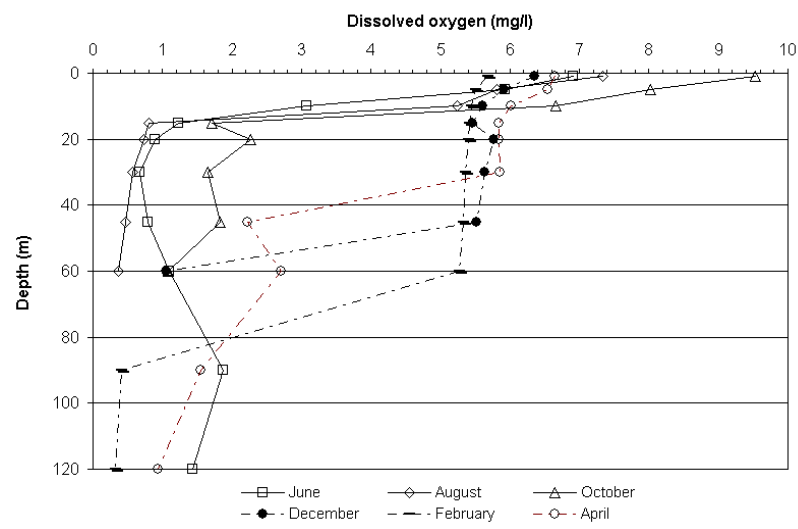

Figure 4: $\quad$ Vertical distribution of dissolved oxygen from June 2008 to April 2009.

Vertical distribution of dissolved oxygen recorded in the Aguamilpa reservoir between June 2008 and April 2009 is shown in fig. 4. In surface waters, dissolved oxygen concentration reached a maximum of $9.53 \mathrm{mg} / \mathrm{l}$ in October 2008 and a minimum of $5.69 \mathrm{mg} / \mathrm{l}$ in February 2009. The water column was characterised by the presence of an oxycline at $10 \mathrm{~m}$ depth from June to October, therefore suboxic and anoxic waters (less than $2 \mathrm{mg} / \mathrm{l}$ ) were present below the oxycline. The dissolved oxygen concentration was evenly distributed along the 
water column down to $45 \mathrm{~m}$ in December 2008 and February 2009 and below this depth, an oxycline was formed in both months. Suboxic and anoxic conditions were always found below $60 \mathrm{~m}$ during the study period. Eh profiles (fig. 5) verified the existence of an anoxic layer below $20 \mathrm{~m}$ in June and August 2008, below $45 \mathrm{~m}$ in December 2008 and below $60 \mathrm{~m}$ in February and April 2009.

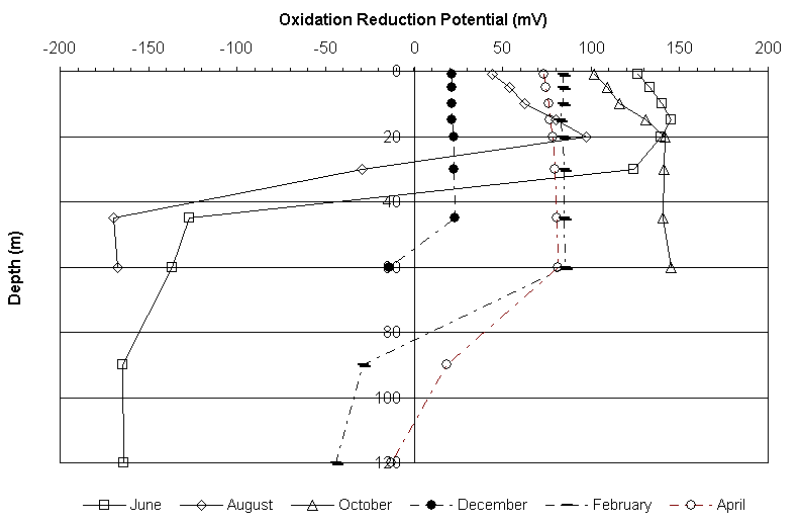

Figure 5: Oxidation reduction potential vertical profiles during the study period.

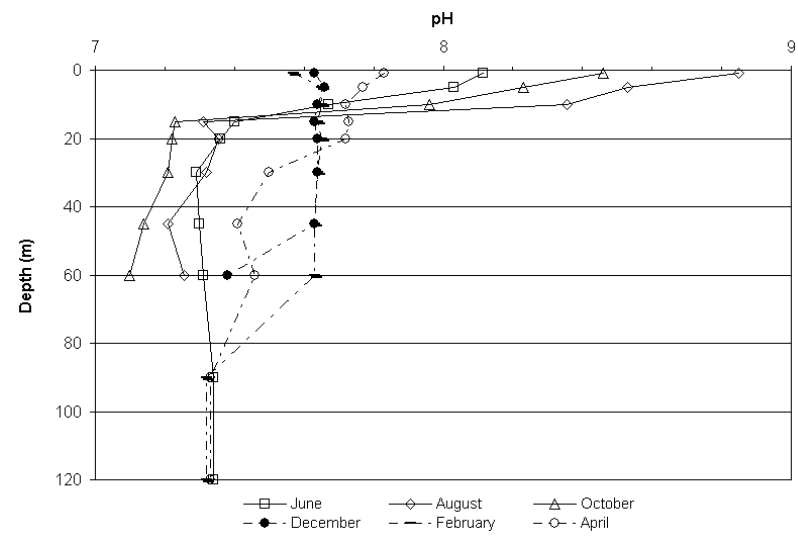

Figure 6: $\mathrm{pH}$ values measured in Aguamilpa reservoir from June 2008 to April 2009.

The water column was stratified with respect to $\mathrm{pH}$ during the months of June, August and October 2008 (fig. 6). In those months, surface $\mathrm{pH}$ values were alkaline and varied from 8.12 to 8.85 . An abruptly decrease, around 7.3 , from surface down to $10-15 \mathrm{~m}$ was recorded for that period, and below $20 \mathrm{~m}$ the $\mathrm{pH}$ remains almost constant around 7.2. The behaviour for $\mathrm{pH}$ during December 2008 and February 2009 was similar to that observed for dissolved oxygen. In 
those months, the $\mathrm{pH}$ was almost constant, 7.64, down to $50 \mathrm{~m}$, and decreasing to 7.32 in the anoxic zone. The $\mathrm{pH}$ slightly increased at surface layers during April 2009.

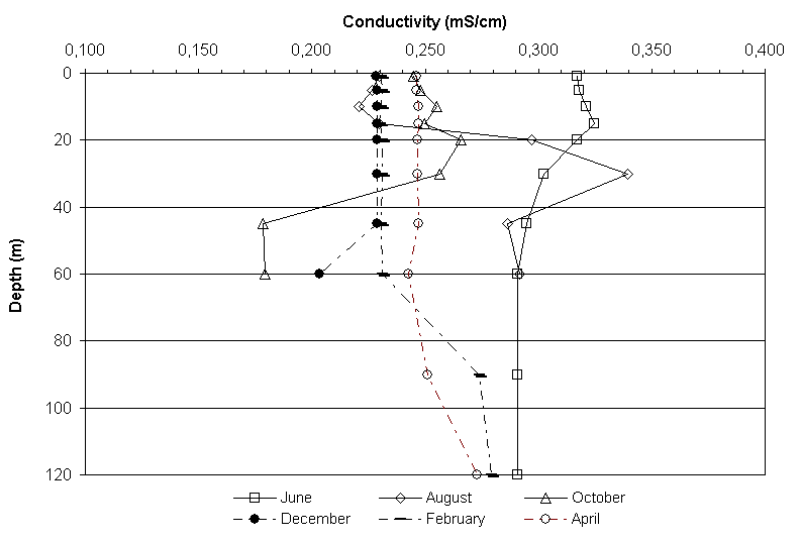

Figure 7: Conductivity values measured in Aguamilpa reservoir from June 2008 to April 2009.

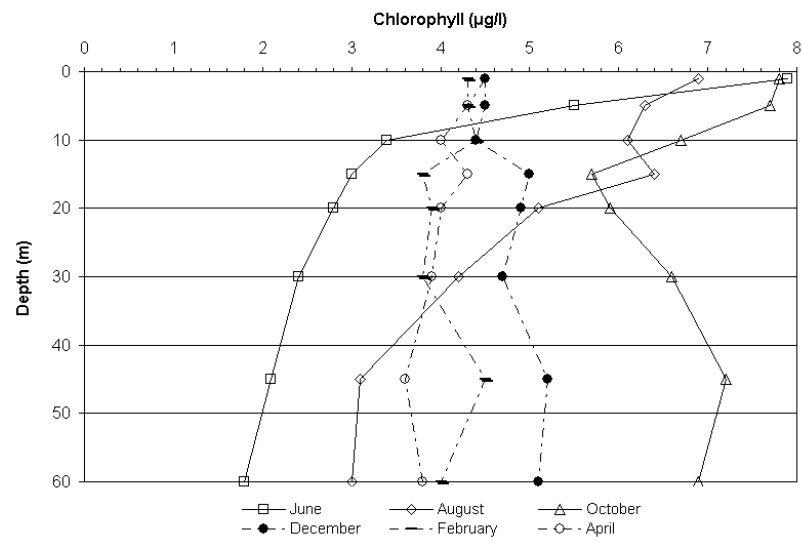

Figure 8: $\quad$ Vertical distribution of total chlorophyll from June 2008 to April 2009.

Conductivity showed high fluctuations during the study period (fig. 7). At the water surface, the lowest values occurred in the cold dry season (December 2008 and February 2009) with a minimum of $0.229 \mathrm{mS} / \mathrm{cm}$ at the beginning of December 2008. Highest values were recorded in the rainy season, where the maximum value $(0.340 \mathrm{mS} / \mathrm{cm})$ was observed at $30 \mathrm{~m}$ depth. On the other hand, vertical distribution of conductivity, down to $50 \mathrm{~m}$, was homogeneous during the cold dry season, with a value of $0.231 \mathrm{mS} / \mathrm{cm}$. At higher depth a slight decrease 
was recorded in December 2008, and a slight increase (below $60 \mathrm{~m}$ ) in February and April 2009 reaching values of $0.279 \mathrm{mS} / \mathrm{cm}$ and $0.273 \mathrm{mS} / \mathrm{cm}$, respectively.

The highest concentrations of total chlorophyll $(7.9 \mu \mathrm{g} / \mathrm{l})$ were measured at the surface in June and August 2008 (fig. 8). Total chlorophyll concentration in deeper waters progressively declined in both months to values of 1.8 and $3.1 \mu \mathrm{g} / \mathrm{l}$ at $60 \mathrm{~m}$ depth. The lowest concentrations of total chlorophyll at the surface, around $4.3 \mu \mathrm{g} / \mathrm{l}$, were measured in December 2008 and February and April 2009. The water column concentrations of total chlorophyll during those months were in the range between $3.6 \mu \mathrm{g} / \mathrm{l}$ and $5.3 \mu \mathrm{g} / \mathrm{l}$.

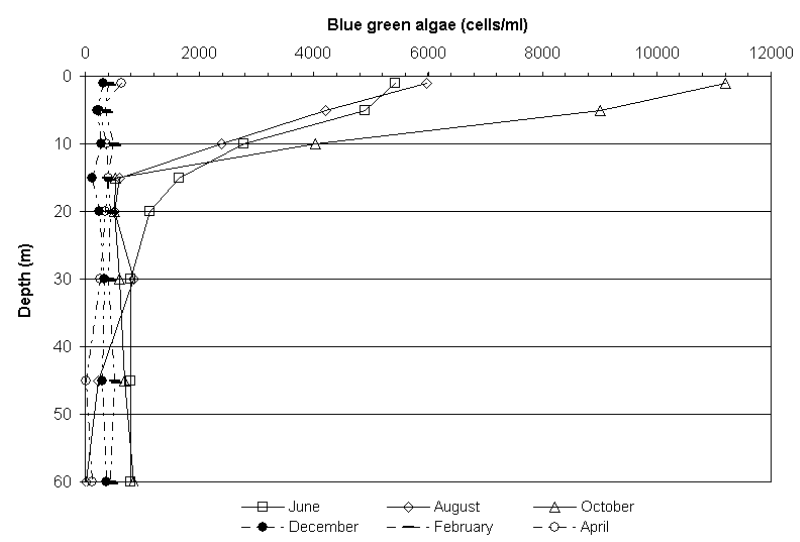

Figure 9: Vertical distribution of blue-green algae density measured from June 2008 to April 2009.

The presence of blue-green algae was always detected in the surface waters of Aguamilpa reservoir during the sampling period. The highest abundance $(11,200$ cells/ml) was found at surface in October 2008 (fig. 9). During the rainy season, vertical distributions of blue-green algae densities showed an abrupt decrease below the depth of $5 \mathrm{~m}$, with less abundance variation from 15 to $60 \mathrm{~m}$ depth. On the other hand during the cold dry season, the cell densities of blue-green algae ranged between 125 and 508 cells $/ \mathrm{ml}$, with a homogeneous distribution through the water column.

\section{Discussion}

The uptake of heat from solar radiation by reservoir water and the gain of heat from air temperature by convection result in structural changes in the water column in tropical water bodies [7, 21]. According to the aforementioned studies, the increase of temperature of Aguamilpa surface waters from $25.9^{\circ} \mathrm{C}$ in June 2008 to $29.1{ }^{\circ} \mathrm{C}$ in October 2008 , generates a termocline in the dry warm and rainy seasons in the upper $60 \mathrm{~m}$ of the water column, below this depth temperature remains almost constant for each season down to $120 \mathrm{~m}$. During the cold dry season surface water temperatures diminish, being lower in February 
2009 than in December 2008 and April 2009. Due to the cooling of surface waters in those months, the termocline breaks leading to a thermal homogenization of the water column. Similar results were found in other tropical water bodies like Arenal reservoir in Costa Rica [22] and Oyun reservoir in Nigeria [23].

The formation of the picnocline, mainly due to temperature, is reinforced by the increase of conductivity levels in bottom waters, as can be observed during February and April 2009. This increase is due to the incoming of salts and sediment particles coming from shoreline erosion during the rainy season. This situation agrees with the observations in other tropical water bodies, such as Agua Fria Reservoir in Venezuela [24] and Lake Tanganyika in East Africa [25], and temperate lakes such as Lake Pavin in France [26] and Lake Iseo in Italy [27], where a chemocline was identified due to the high conductivity levels recorded at lower layers. The accumulation of the alloctonous organic materials in Aguamilpa bottom waters changed the redox conditions (fig. 10) due to the decomposition of the organic matter [3, 28, 29], a process that generates the anoxic conditions in bottom waters. In addition, the oxygen deficit in bottom waters can also be related to water body depth [30-32].

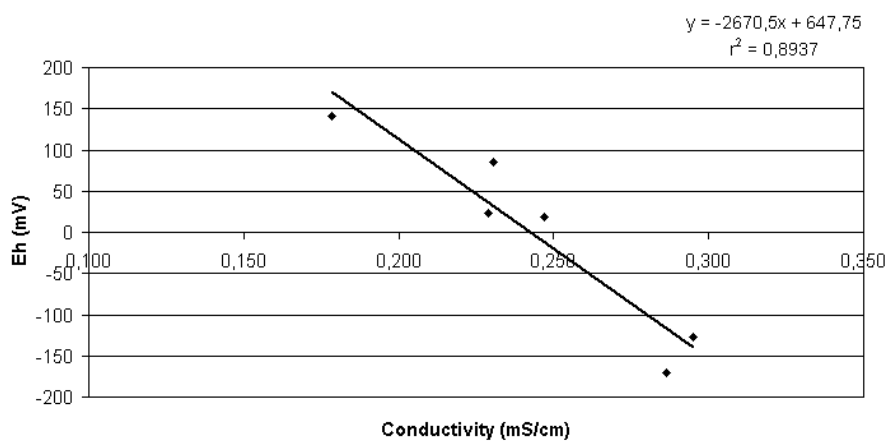

Figure 10: Correlation between oxidation reduction potential and conductivity from June 2008 to April 2009 at $45 \mathrm{~m}$ depth.

Owing to the great depth of the sample site, the slight variation in air temperature through the year, distinctive to the tropical region where the reservoir is located, and the physico-chemical properties of the water column observed in this study, the lenthic zone of Aguamilpa reservoir is proposed as biogenic meromictic according to Hutchinson's [33] classification.

Since oxycline was identified at $60 \mathrm{~m}$, morphometric variations on the reservoir may also change circulation patterns and probably may develop warm monomictic patterns as usually occurs in tropical reservoirs [7, 34]. This situation is very important in Aguamilpa reservoir because the water used for power generation is taken at $170 \mathrm{~m}$.a.s.1. (around $60 \mathrm{~m}$ depth), therefore passing anaerobic waters through turbines or other machinery may cause severe damage to the equipment. 
The highest abundance of blue-green algae was detected during the dry warm and rainy season (June to October 2008). This fact may be related to the increase of air and water surface temperature, nutrient enrichment in the reservoir originated by the runoff from catchment area, and long periods of calm winds. The narrow morphology of the reservoir featured by high steep canyon walls and the low air temperature variation within the day, diminishes the advective wind forces on the water surface during this period. This situation agrees with studies in other countries such as New Zealand [35], North America [36], Italy [37] and Poland [38]. When algal blooms occurred on the surface of Aguamilpa reservoir, they were easily recognised by the resulting scum, which looks like blue-green paint. The significance of these blooms is the fact that some blue-green algal species are known to produce chemicals that can be toxic to animals and humans, when present in hazardous densities in water bodies [39, 40]. On the other hand, algal blooms also tend to be symptomatic of the later stages of eutrophication $[41,42]$.

According to Wetzel [30], the blue-green algae are usually much more tolerant to high temperatures than eukariont algae that inhabit the same system. Temperatures above $20^{\circ} \mathrm{C}$ and increase of dissolved material contribute to the maximum competitiveness and subsequent increase of blue-green algae abundance in the system [43]. Therefore, the local climatic and hydrological conditions during the rainy season and site specific characteristics favoured the development of such algal blooms in Aguamilpa reservoir.

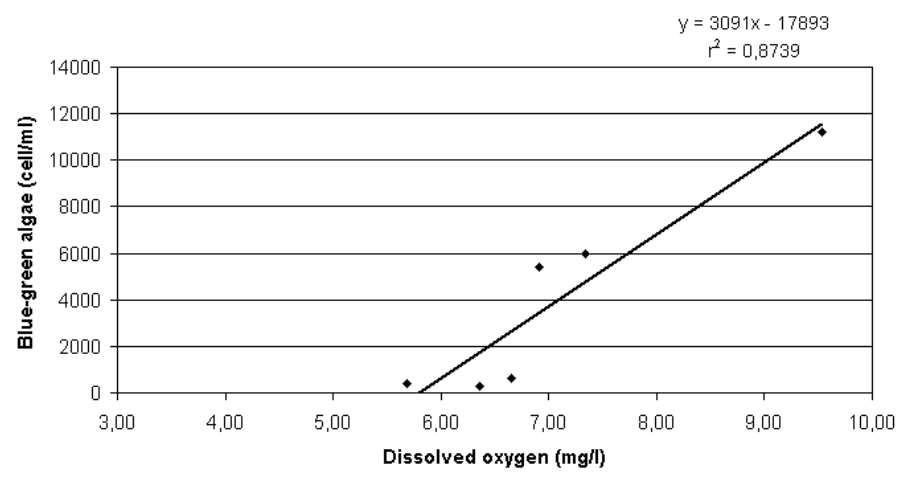

Figure 11: Correlation between blue-green algae and dissolved oxygen at $1 \mathrm{~m}$ depth through the study period.

At present, there is insufficient information available for use concerning maximum allowable concentrations for blue-green algae in a water body for the different water uses. The Australian National Health and Medical Research Council [44] suggests that blue-green algae levels below 20000 cells $/ \mathrm{ml}$ can be considered as low and it also recommends that in case of algal bloom occurrence, an alternative source of irrigation and drinking water be used. Therefore under this criterion, the upper layers of Aguamilpa reservoir, down to $15 \mathrm{~m}$, is not suitable for any of the aforementioned uses during warm dry seasons and rainy seasons. 
Dissolved oxygen in the surface waters is the result of interaction between atmospheric oxygen, algal photosynthetic activity and the chemical and biochemical oxidation of organic matter [30]. Particular significance is attached to the mixolimnion layer which was continuously mixed during the study period and reached its best aeration precisely during the rainy season when blue-green algae density was maximum (fig. 11). Oxygen production by photosynthesis of blue-green algae in surface layers, and its diurnal oversaturation, has been well recognized in some studies $[45,46]$.

According to Chapman [3], surface runoff within catchments area may increase the water $\mathrm{pH}$ values during the rainy season. However in this study, the increase of $\mathrm{pH}$ was only detected at surface layers during the rainy season. Figure 12 shows that this situation is associated with the abundant presence of blue-green algae. Meybeck [47] and Ghosh et al. [48] indicate that the dissolved oxygen and $\mathrm{pH}$ increase in surface layers, caused by the photosynthetic activities, may be associated with an eutrophication process in the reservoir.

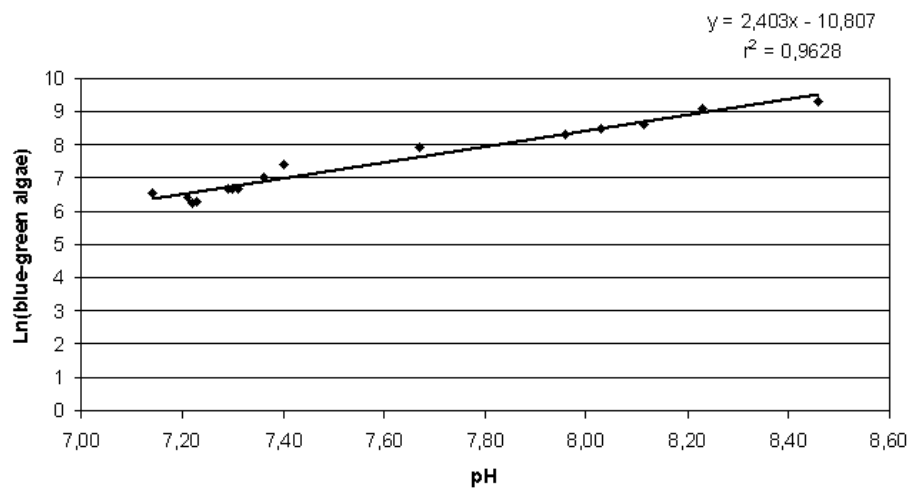

Figure 12: Correlation between blue-green algae and $\mathrm{pH}$ through water column in June 2008 and October 2008.

Measurement of chlorophyll pigments provides an approximate indication of algal biomass. In general, the highest total chlorophyll concentration was located at the surface (1 m depth). An abrupt decrease of total chlorophyll concentration through the water column was observed in June 2008 when the supply of nutrients from lower layers is suppressed due to thermal stratification. Nevertheless, the partial vertical mixing observed in the water column during the cold dry season showed an influence on the total chlorophyll concentration profile which was homogeneous as a result of nutrients supply from deep waters, observed at the end of the warm dry and during the rainy season. According to OECD [49], water bodies with low levels of nutrients in temperate latitudes (e.g. oligotrophic lakes) have low levels of mean chlorophyll a $(<2.5 \mu \mathrm{g} / \mathrm{l})$ whereas waters with higher nutrient contents (especially those classed as mesotrophic) reach levels of mean chlorophyll a of 2.5 to $8.0 \mu \mathrm{g} / \mathrm{l}$ and a maximum of $25 \mu \mathrm{g} / \mathrm{l}$. Since the highest levels of total chlorophyll measured at surface waters in Aguamilpa reservoir was observed at the end of warm dry and during rainy 
season, reaching a maximum value of $7.9 \mu \mathrm{g} / 1$, the trophic state of the reservoir may be considered in the mesotrophic range.

\section{Conclusions}

Based upon the thermal characteristics of the water body, as a result of climatic conditions distinctive of tropical latitudes and due to mixing features observed through the water column of some water quality parameters, such as conductivity and dissolved oxygen, the lenthic zone of Aguamilpa reservoir shows a meromictic thermal pattern.

The analysis of physicochemical and primary productivity data including blue-green algae density at different depths during the period of June 2008 to April 2009 indicates an advanced eutrophication in Aguamilpa reservoir.

Noteworthy is the observed high density of blue-green algae present in surface waters at the end of the warm dry season and during the rainy season. This fact was found to be strongly associated with the increase of air temperature in the region, the presence of nutrients in the water column, and was favored by the particular morphologic features of the reservoir.

\section{Acknowledgements}

The authors thank CFE for the hydrological and climatic information provided, and the Instituto de Geografía de la Universidad Nacional Autónoma de México for the digital information of study area. Likewise, we thank MC Yazmín Jarquín Javier for her support in image processing and CONACYT Basic Science funds (CB-CONACYT 2006-58119) for their support in the development of this work and for the scholarship awarded to the first author.

\section{References}

[1] WCD, Dams and Development. Technical report, World Commission on Dams, London, United Kingdom, pp. 3-8, 2000.

[2] Meybeck, M. \& Helmer, R., The quality of Rivers: from pristine stage to global pollution. Global Planetary Change, pp. 283-309, 1990.

[3] Chapman, D.V., Water Quality Assessments: A guide to the use of biota, sediments and water in environmental monitoring, E\&FN Spon., World Health Organization, Cambridge, United Kingdom, 609 p., 1996.

[4] Melack, J.M., Recent developments in tropical limnology. Verh. Internat. Verein. Limnol., 26, pp. 211-216, 1996.

[5] Casallas, J.E. \& Gunkel, G., Algunos aspectos limnológicos de un lago alto andino: el lago San Pablo, Ecuador. Limnetica 20(2), pp. 215-232, 2001.

[6] Talling, J.F. \& Lemoalle, J., Ecological dynamics of tropical inland waters. Cambridge University Press, Cambridge, pp. 4-8, 1998.

[7] Lewis, W.M., Basis for the protection and management of tropical lakes. Lakes \& Reservoirs: Research and Management, 5, pp. 35-48, 2000. 
[8] CONAGUA, Estadísticas del agua en México. Edición 2008., Secretaría de Medio Ambiente y Recursos Naturales, México, pp. 66-70, 2008.

[9] de Victorica-Almeida, J. L. Análisis de la dinámica de la calidad del agua en lagos y embalses. Tesis doctoral, División de Estudios de Posgrado de la Facultad de Ingeniería, Universidad Nacional Autónoma de México, 143 p., 1995.

[10] de Victorica-Almeida, J.L., Modelo para simular la evolución de oxigeno disuelto en embalses. Ingeniería del Agua, 3(2), pp. 63-74, 1996.

[11] Aranguré-Zuñiga, F.J., Contaminación por residuos de Plaguicidas Organoclorados en Sedimentos y Peces de la Presa Hidroeléctrica Aguamilpa, Nayarit, México, Tesis para obtener el grado de Maestro en Ciencias por el Instituto Tecnológico de Tepic, México, 113 p., 2005.

[12] Zambrano-Cárdenas, R.M., Niveles de Contaminación por Metales Pesados en Sedimentos y Peces de la Presa Aguamilpa, Nayarit, Tesis para obtener el grado de Maestro en Ciencias por el Instituto Tecnológico de Tepic, México, 96 p., 2005.

[13] García-Cabrera, J., Plancton como indicador de calidad del agua en la presa de Aguamilpa. Ingeniería Hidráulica en México. 22(1), pp. 103-116, 2007.

[14] Comisión Estatal del Agua del Estado de Jalisco (CEA Jalisco), Resultados del Monitoreo del Arroyo El Ahogado y Río Santiago, Jalisco, México, Online. http://www.ceajalisco.gob.mx/notas/documentos/ nota_resultados_monitoreo2.pdf

[15] Navarro-Rodríguez, M.C., Flores-Vargas, R., González-Guevara, L.F. \& González-Ruelas, M.E., Distribution and abundance of Dormitator latifroms (Richarson) larvae (Pisces: Eliotridae) in the natural protected area "Estero El Salado" in Jalisco, Mexico. R. de Biol. Marina $y$ Oceanografía. 39(1), pp. 31-36, 2004.

[16] CFE, Proyecto hidroeléctrico Aguamilpa, Información General del Proyecto Aguamilpa, Mexico, pp. 21-23, 1991.

[17] HongQi, M.A. \& KeMing, C.A.O., Key technical problems of extra-high concrete faced rock-fill dam. Sci. China Ser. E-Tech. Sci., 50(1), pp. 20-33, 2007.

[18] APHA, Standard Methods for Examination of Water and Waste Water. $21^{\text {st }}$ edition, American Water Works Association, Water Environment Federation, Washington DC., Part-4500-0, pp. 1-141, 2005.

[19] YSI, Multiparameter Water Quality Sondes. User Manual, Yellow Springs Instruments, Sections 5-21 and 5-31, pp. 253 -268, 2008.

[20] CFE, Registro de observaciones hidrométricas y climatológicas en el embalse de Aguamilpa, Online. http://h06814.iie.org.mx/presascfe/ semanapresacaracol.aspx?estacion $=$ agu

[21] Watanabe, M., Horiuchi, S. \& Ambre, Y., Sudden changes of thermal stratification in meromictic lake, Lake Kaiike, Japan. Verh. Internat. Verein. Limnol. 27, pp. 261-264, 2000.

[22] Villalobos, G.U., Ciclo anual de estratificación y circulación en el Embalse Arenal, Costa Rica. Rev. Biol. Trop. 54(1), pp. 257-263, 2006 
[23] Mustapha, M.K., Assessment of the Water Quality of Oyun Reservoir, Offa, Nigeria, Using Selected Physico-Chemical Parameters. Turk. J. Fish. Aquat. Sci., 8, pp. 309-319, 2008.

[24] Gonzalez, E.J., Carrillo, V. \& Peñaherrera, C., Características Físicas y Químicas del Embalse Agua Fría (Parque Nacional Macarao, Estado Miranda, Venezuela). Acta Cientifica Venezolana, 55, pp. 225-236, 2004.

[25] De Wever, A., Muylaert, K., Van der Gucht, K., Pirlot, S., Cocquyt, C., Descy, J.P., Plisnier, P.D. \& Vyverman, W., Bacterial Community Composition in Lake Tanganyika: Vertical and Horizontal Heterogeneity. Appl. Environ. Microbiol., 71(9), pp. 5029-5037. 2005.

[26] Lehours, A.C., Bardot, C., Thenot, A., Debroas, D. \& Fonty, G., Anaerobic Microbial Communities in Lake Pavin, a Unique Meromictic Lake in France. Appl. Environ. Microbiol., 71(11), pp. 7389-7400, 2005.

[27] Ambrosetti, W. \& Barbanti, L., Evolution towards meromixis of Lake Iseo (Northern Italy) as revealed by its stability trend. J. Limnol., 64(1), pp. 111, 2005.

[28] Löffler, H., The origin of lake basins (Chapter 2). The lakes handbook Vol. 1, ed P.E. O’Sullivan \& C.S. Reynolds, Oxford Science Ltd. Blackwell Publ. Co., pp. 8-60, 2004.

[29] Denimal, S., Bertrand, C., Mudry, J., Paquette, Y., Hochart, M. \& Steinmann, M., Evolution of the aqueous geochemistry of mine pit lakes Blanzy-Montceau-les Mines coal basin (Massif Central, France): origin of sulfate contents; effects of stratification on water quality. Applied Geochemistry, 20, pp. 825-839, 2005.

[30] Wetzel, R.G., Limnologia. Fundacao Calouste Gulbenkian, Lisboa, 919 p. 1993.

[31] Hakanson, L., The importance of Lake Morphometry for the Structure and Function of Lakes. Internat. Rev. Hydrobiol., 90(4), pp. 433-461, 2005.

[32] Hayami, Y., Ohmori, K., Yoshino, K. \& Garno, Y.S., Observation of anoxic water mass in a tropical reservoir: the Cirata Reservoir in Java, Indonesia. Limnology, 9, pp. 81-87, 2008.

[33] Hutchinson G.E., A contribution to the limnology of arid regions. Trans. Conn. Acad. Arts Sci. 33, pp. 47-132. 1937.

[34] Tundisi, J.G., Tropical South America: Present and perspectives. Limnology Now: A Paradigm of Planetary Problems, ed R. Margalef, Elsevier: Amsterdam, pp. 353-424, 1994.

[35] Stirling, D.J. \& Quilliam, M.A., First report on the cyanobacterial toxin cylindrospermopsin in New Zealand. Toxicon., 39, pp. 1219-1222, 2001.

[36] Burns, J., Williams, C. \& Chapman, A., Cyanobacteria and their toxins in Florida surface waters. Proc. of health effects of exposure to cyanobacteria toxins, eds. D. Johnson \& R.D. Harbison, State of science, Saratoga, Florida, pp. 16-21, 2002.

[37] Manti, G., Mattei, D., Messineo, V., Melchiorre, S., Bogialli, S., Sechi, N., Casiddu, P., Luglio, L., Di Brizio, M. \& Bruno, M., First report of Cylindrospermopsis raciborskii in Italy. Harmful Algal News, 28, pp. 8-9, 2005. 
[38] Mankiewicz, J., Komárková, J., Izydorczyk, K., Jurczak, T., Tarczynska, M. \& Zalewski, M.. Hepatotoxic cyanobacterial blooms in the lakes of northern Poland. Environ. Toxicol,. 20(5), pp. 499-506, 2005.

[39] Carmichael, W.W., Azevedo, S.M., An, J.S., Molica, R.J., Jochimsen, E.M., Lau, S., Rinehart, K.L., Shaw, G.R. \& Eaglesham, G.K., Human fatalities from cyanobacteria: Chemical and biological evidence for cyanotoxins. Environ. Health Perspect., 109, pp. 663-668. 2001.

[40] Falconer, I.R. \& Humpage, A.R., Cyanobacterial (Blue-Green Algal) Toxins in Water Supplies: Cylindrospermopsins. Environ. Toxicol., 21, pp. 299-304, 2006.

[41] Dokulil, M.T. \& Teubner, K. Cyanobacterial dominance in lakes. Hydrobiologia, 438, pp. 1-12. 2000.

[42] Fastner, J., Rücker, J., Stüken, A., Preußel, K., Nixdorf, B., Chorus, I., Köhler, A. \& Wiedner, C., Occurrence of the Cyanobacterial Toxin Cylindrospermopsin in Northeast Germany. Environ. Toxicol., 22, pp. 2632, 2007.

[43] Marques-Lopes, M.R., Bicudo, C.E.M. \& Ferragut, M.C., Short term spatial and temporal variation of phytoplankton in a shallow tropical oligotrophic reservoir, southeast Brazil. Hidrobiologia, 542, pp. 235-247, 2006.

[44] NHRMC, Australian Drinking Water Guidelines, National Health and Medical Research Council, Australia, pp. 259-263, 2004.

[45] Kuroiwa, K., Ogawa, Y., Seki, H. \& Ichimura, S. Dynamics of dissolved oxygen in a hypereutrophic lake: Lake Kasumigaura, Japan. Water, Air and Soil Pollution. 12, pp. 255-264, 1979.

[46] Masojídek, J., Grobbelaar, J.U., Pechar, L. \& Koblízek, M., Photosystem II Electron Transport Rates and Oxygen Production in Natural Waterblooms of Freshwater Cyanobacteria During a Diel Cycle. J. Plankton Res. 23, pp. 57-66, 2001.

[47] Meybeck, M., Le lacs et leur bassin versant. Limnologie Général, ed. R. Pourriot \& M. Meybeck, Masson, Paris, pp. 6-60. 1995.

[48] Ghosh, A.K., Kumar, P. \& Bose, N. Study of trophic status of a pond through diurnal profiling. Oceans 2003 Proc., 3, pp. 1199-1204, 2003.

[49] Vollenweider, R.A. Scientific fundamentals of the eutrophication of lakes and flowing waters, with particular reference to nitrogen and phosphorus as factors in eutrophication. Technical Report DAS/CSI/68.27, Environmental Directorate, Organization for Economic Cooperation and Development (OECD), Paris, 134 p., 1968.

[50] DOF, Diario Oficial de la Federación. Lunes 28 de Agosto de 2006, Segunda Sección. Poder Ejecutivo. Secretaria de Medio Ambiente y Recursos Naturales. 128 p., 2006. 